\title{
ELASTO-PLASTIC WIND-INDUCED RESPONSE EVALUATION OF A PASSIVELY CONTROLLED HIGH- RISE BUILDING WITH HYSTERETIC DAMPER
}

平塚紘基 $-* 1 \quad$ 佐藤大樹 $-* 2$
田中英之一 -2

キーワード

超高層制振建物，履歴型ダンパー，多質点系モデル，弾塑性風応答

Keywords:

Passively controlled high-rise building, Hysteretic damper, MDOF model, Elasto-plastic wind-induced response

\section{1. はじめに}

地震時における超高層建物の構造体の損傷制御や応答制御を目的 として, 建物に制振部材を付加する制振構造は多く採用されている。 履歴減衰型ダンパー（以下，ダンパー）を用いる場合，できるだけ小 さな荷重レベルから早期にダンパーを塑性化させることで，エネル ギー吸収を積極的に行うことができる。一方で, 超高層建物を対象と した場合，風外力が建物の高層化に伴い構造設計において支配的な 荷重となる恐れがあるものの，現状の耐風設計では想定される最大 級の強風に対して, 主要な構造体を弾性状態で留めるように設計が 行われている。これは, 強風は地震に比べ継続時間が圧倒的に長いこ とから部材などの疲労損傷の恐れがあること，構造骨組の塑性化に よって建築物の固有周期が長くなると, 固有周期に対応寸るパワー が増し, 風荷重が大きくなること, 風の作用寸る建築物の弾塑性挙動 についてほとんど情報がないということが理由として挙げられる ${ }^{1)} 。$ しかし, 地震に対する制振効果を得るために, 超高層建物に低い荷重 レベルで塑性化させるダンパーを採用すると，風外力に対しても塑 性化することが考えられる。よって, 耐震設計と同様に耐風設計にお いても，弾塑性応答を評価することは必要不可欠である。

制振構造の弾塑性風応答を評価するためには，一般的に時刻歴応 答解析を用いる必要がある。しかし，風外力を用いて超高層建物を対 象に時刻歴応答解析を行うと, 地震に比べ圧倒的に継続時間が長い こと ${ }^{1)}$, 多数の時刻歷応答解析を行い, 応答值をアンサンブル平均す

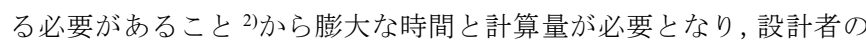
大きな負担となる。そのため, 風荷重に対する弾塑性風応答時におけ る建物の挙動を実用的に評価するために時刻歴応答解析を用いない 手法が求められている。

弾塑性風応答予測に関する研究はこれまでいくつか行われている
Koki HIRATSUKA $-* 1$
Hideyuki TANAKA $-* 3$

Daiki SATO $* 2$

In the current wind-resistant design code, buildings are designed to remain elastic. As they become taller, however, wind force on them tends to increase drastically thereby making them more susceptible to plastic deformation. It is, therefore, vital to evaluate the elasto-plastic response of high-rise buildings to wind forces. As such, this paper proposes an elasto-plastic wind-induced multi-degree-of-freedom response prediction method for a passively controlled high-rise building with hysteretic dampers, and examines the accuracy of the proposed method.
例えば 3),44。吉江ら ${ }^{4)}$ は, 構造物の風応答をエネルギー収支の観点から 整理・分析することで, エネルギーの釣合に基づく応答予測手法を提 案している。しかし, 提案されている弾塑性風応答予測手法の多くは, 1 質点系での検討に留まっている。実際の構造物の設計に応用するた めには, 多質点系での検討が必要であるものの，これまで多質点系で の弾塑性風応答予測手法に関する研究はわずかである例えば5),6)

そこで本報では，履歴型ダンパーを有する超高層制振建物を対象 とし, 多質点系での風応答（最大変形）予測手法を提案し，その精度 について示すことを目的とする。なお, 本報では構造物の振動により 風力特性が変化しないことを前提とし, 空力不安定振動の問題は対 象外とする。また，変動成分のみの風直交方向風力を対象とする。

\section{2. 解析対象モデルおよび風外力概要}

\section{1 解析対象モデル}

本報では, 超高層制振建物を対象とし, 高さ $H=200 \mathrm{~m}$ の 20 質点 せん断型モデルを用いる。フレームを文献 7) と同様に，1 次固有周期 ${ }_{1} T_{f}=5.0 \mathrm{~s}$, 建物密度 $\rho_{f}=175 \mathrm{~kg} / \mathrm{m}^{3}$ とし, 質量は高さ方向に一様と想 定した。辺長比は $D / B=1(D, B$ : 建築物の奥行, 幅, $D=B=40 \mathrm{~m})$ とし, 構造減衰を剛性比例型として, ${ }_{1} T_{f}$ に対して, 1 次減衰定数 ${ }_{1} \xi_{f}$ $=1 \% ， 2 \% ， 4 \% （ 4 \%$ は粘性ダンパーの併用を想定）の 3 種類を用い る。各層のフレームの剛性 $k_{f i}$ （Fig. 1) は建物の 1 次固有モードが直 線 $^{8)}$ となるように設定した。なお，フレームは弾性とする。

本報で用いるダンパーは完全弾塑性としてモデル化する。1 層目の ダンパー降伏せん断力係数 (以下, ダンパー量) $\alpha_{d v 1}$ は $0.01,0.02$ の 2 種類とし, ダンパーの降伏層間変形角 $R_{d y}$ は, $1 / 600$ とする。各層の ダンパー降伏層せん断力 $Q_{d y i}$ は, 第 1 層目のダンパー降伏層せん断 力 $Q_{d y 1}$ を基準とし, $\mathrm{Ai}$ 分布に基づく設計用地震層せん断力分布をも
東京工業大学環境・社会理工学院 大学院生

（干 226-8503 神奈川県横浜市緑区長津田町 4259)

東京工業大学未来産業技術研究所 准教授・博士（工学）

(㑣竹中工務店技術研究所 主任研究員・博士 (工学)
Graduate Student, School of Environment and Society, Tokyo Institute of Technology

Assoc. Prof., FIRST, Tokyo Institute of Technology, Dr. Eng.

3 Chief Researcher, Research \& Development Institute, Takenaka Corporation, Dr. Eng. 


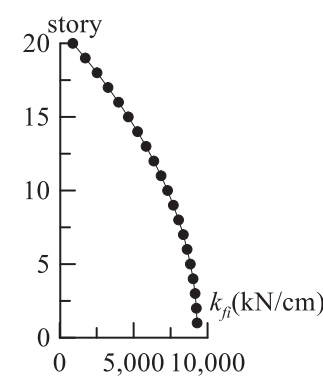

Fig. 1 Stiffness (frame)

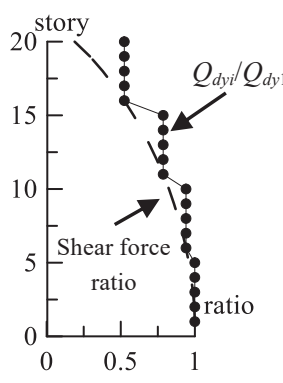

Fig. 2 Yield strength ratio

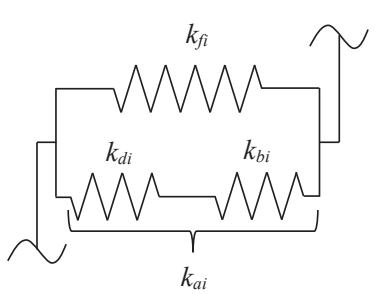

Fig. 3 Model of frame with Additional component

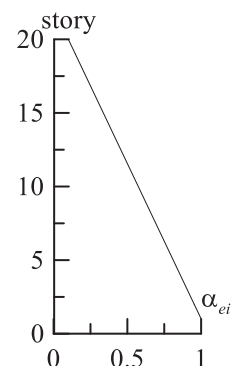

Fig. 4 Effective damper deformation ratio

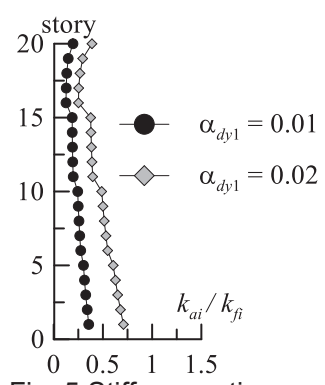

Fig. 5 Stiffness ratio $\left(k_{a i} / k_{f i}\right)$

とに 4 段階とする（Fig. 2)。 $Q_{d y 1}$ は， $\alpha_{d y 1}$ を用いて次式で表される。

$$
Q_{d y 1}=\alpha_{d y 1} \cdot W
$$

ここで, $W$ : 全重量を表す。ダンパーの降伏変形 $\delta_{d y i}$ は $R_{d y}$ および質点 間距離 $h_{i}$ を用いて以下の式で表される。

$$
\delta_{d y i}=R_{d y} \cdot h_{i}
$$

よってダンパー剛性 $k_{d i}$ は式(3)より求められる。

$$
k_{d i}=Q_{d y i} / \delta_{d y i}
$$

しかし，モデル化したダンパーを，フレームをモデル化したバネに並 列に配置したせん断型モデルに用いると，ダンパーに有効に働く変 形（実効変形）を過大に評価することとなり危険側の評価となる ${ }^{9}$ 。 そこで本報では，文献 10) と同様にダンパーの剛性 $k_{d i}$ に実効変形を 過大評価しないための直列バネ剛性 $k_{b i}$ を挿入したせん断型モデル (Fig. 3) を用いる。以降 $k_{d i}$ と $k_{b i}$ の直列系 $k_{a i}$ を付加系 (Additional component）の剛性と呼ぶ。 $k_{a i}$ を算出する際に用いる層間変形に対す る実効変形の比（実効変形比） $\alpha_{e i}$ は, 文献 11)を参考に第 1 層目から 第 20 層目まで直線となるように仮定し，第 1 層目を 1 , 第 20 層目を 0.1 とする (Fig. 4)。また, 付加系降伏層せん断力 $Q_{a y i}$ は $Q_{d y i}$ と同值 である。以上の条件から，付加系の剛性 $k_{a i}$ は以下の式で表される。

$$
k_{a i}=Q_{a y i} /\left(\delta_{d y i} / \alpha_{e i}\right)
$$

なお, 付加系の降伏変形 $\delta_{a y i}$ は以下の式で表される。

$$
\delta_{a y i}=\delta_{d y i} / \alpha_{e i}
$$

本報では Fig. 3 に示すようなフレームに付加系を並列に設置したモ デルを以後システムと呼ぶ。システムの 1 次固有周期 ${ }_{1} T$ は， $\alpha_{d y 1}=$ 0.01 で $4.47 \mathrm{~s}, \quad \alpha_{d y 1}=0.02$ で $4.08 \mathrm{~s}$ である。Fig. 5 に,$k_{a i} / k_{f i}$ の高さ方 向分布を示す。なお，付加系は粘性減衰を有さないものとする。

Fig. 6 にフレーム, 付加系, システムの復元力特性を示す。Fig. 6 中 に示す $\delta_{i}$ は $i$ 層の層間変形を表し, $Q_{f i}$ は $\delta_{i}$ 時の $i$ 層のフレーム層せ 几断力を表す。 $i$ 層のシステム降伏層せん断力 $Q_{y i}$ は, Fig.6 に示した 復元力特性より, 以下の算定式より算出される。

$$
Q_{y i}=k_{f i} \cdot \delta_{a y i}+Q_{a y i}
$$

\section{2 風外力概要}

本報では風直交方向のみを対象とする。構造物に作用寸る風外力 は文献 12) と同じ風洞実験結果（地表面粗度区分III）を用いた。層風 力係数の時刻歴データは, 高さ方向に 9 点で測定している。このデ

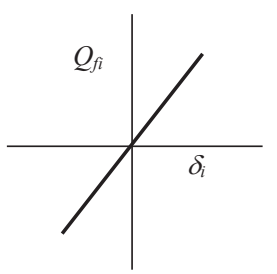

(a) Frame

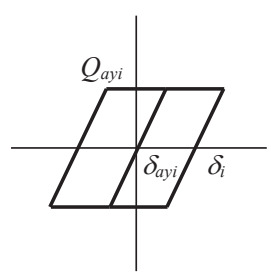

(b) Additional component

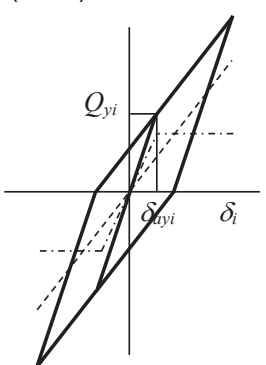

(c) System
Fig. 6 Restoring force characteristic

一タを, 対象建物の高さ, 質点数および基準風速 $U_{0}=36 \mathrm{~m} / \mathrm{s}$ での再 現期間 500 年風外力几変換を行った。なお, 小地形の影響, 季節係数 および風向倸数の影響は考慮していない。また，風向角は $0^{\circ}$ （建物 に正対する方向）であり， 1 組につき 20 質点分の波形を 0.05 秒刻み $14000(700 \mathrm{~s})$ ステップとし，10 組取り出した。

Fig. 7 に本報で用いる風直交方向頂部風外力 $F_{20}$ の時刻歴波形の 1 例を, Fig. 8 に頂部風外力のパワースペクトル密度（PSD） $S_{F 20}$ の 10 波のアンサンブル平均值を示す。本報では時刻歴応答解析の過渡応 答の影響を避けるため, 各波形前後に $50 \mathrm{~s}$ のエンベロープを設け, 中間の $600 \mathrm{~s}$ (10 分間) での応答を評価に用いる。また, 10 波のアン サンブル平均により応答值を評価する。なお, 風洞実験における平均 風速および乱れ強さ, また模型頂部高さでの変動風速の無次元 PSD は附録 $\mathrm{A}$ を参照されたい。

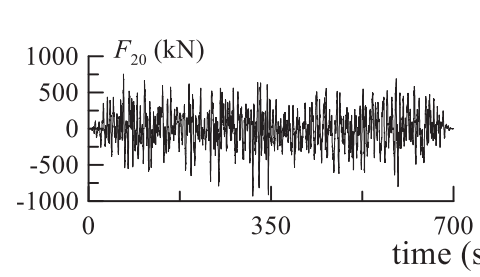

Fig. 7 Time history of wind force

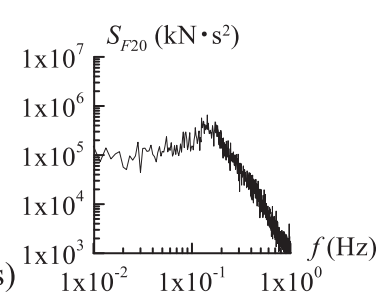

Fig. 8 Power spectral density

\section{3. 弾塑性風応答予測手法}

Fig. 9 に弾塑性風応答予測手法のフローチャートを示す。弾塑性風 応答は，スペクトルモーダル解析を用いた等価線形化により予測す る。ただし, 収斂回数 $j=0$ の場合は, 等価線形化前のシステム弾性 時の值を用いる。

[手順 1] ${ }_{1} \phi^{(j)}{ }_{e q, i,}{ }_{1} f^{(j)}{ }_{e q,},{ }_{1} K^{(j)}{ }_{e q}$ の算出

システム 1 次等価固有モード ${ }_{1} \phi^{(j)}{ }_{e q, I}$ (附録 B), 等価固有振動数 ${ }_{1} f^{(j)}{ }_{e q}$ および等価モーダル剛性 ${ }_{1} K^{(j)}{ }_{e q}$ は，システムの等価剛性 $k^{(j)}{ }_{e q, i}$ $\left(j=0\right.$ の場合, $\left.k^{\left({ }^{(0)}\right.}{ }_{e q, i}=k_{i}=k_{f i}+k_{a i}\right)$ および対象モデルの各層の質量 $m_{i}$ を用いて固有值解析により算出する。 


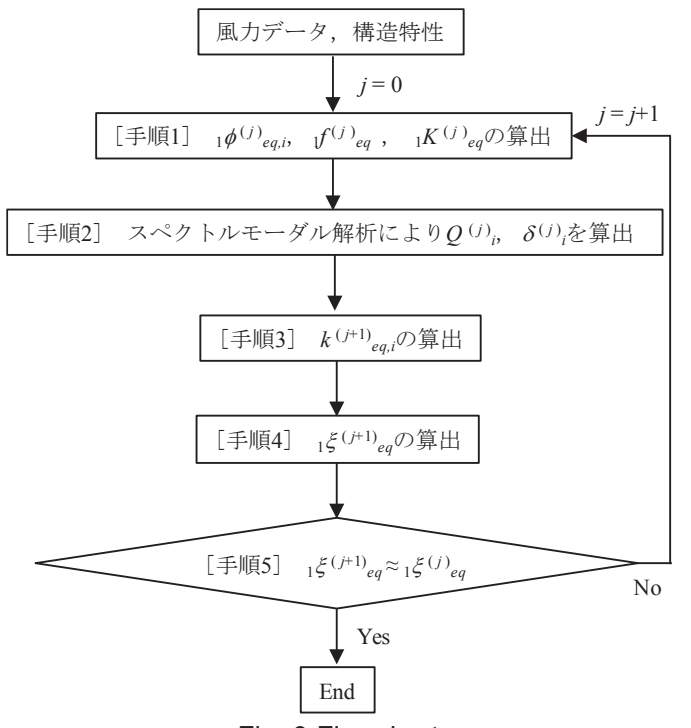

Fig. 9 Flowchart

\section{[手順 2] $Q^{(j)_{i},} \delta^{(j)}{ }_{i}$ の算出}

風力データ, 構造特性および手順 1 より求めた固有值を用いてス ペクトルモーダル解析により, 層せん断力 $Q^{(j)}{ }_{i}$ および層間変形 $\delta^{(j)}$ を算出する。

$i$ 層の風外力時刻歷 $F_{i}(t)$ と ${ }_{1} \phi^{(j)}{ }_{e q, i}$ を用いて, 1 次モーダル風外力時 刻歴 ${ }_{1} F^{(j)}(t)$ は式(7)より算出される。

$$
{ }_{1} F^{(j)}(t)=\sum_{i=1}^{N} \phi^{(j)}{ }_{e q, i} \cdot F_{i}(t)
$$

ここで, $N$ : 層数を表す。 1 次モーダル風外力のパワースペクトル密 度 ${ }_{1} S^{(j)}{ }_{F}(f)$ とシステム 1 次等価モーダル剛性 ${ }_{1} K^{(j)}{ }_{e q}$ およよ゙ 1 次等価 減衰定数 ${ }^{\left({ }^{(j)}\right.}{ }$ q を用いて, スペクトルモーダル解析により, 1 次モー ダル応答変位 ${ }_{1} q^{(j)}$ の標準偏差 ${ }_{1} \sigma^{(j)}{ }_{q}$ は式(8)より算出される。

$$
{ }_{1} \sigma_{q}^{(j)}=\left[\int_{0}^{\infty}\left|{ }_{1} H^{(j)}(f)\right|^{2} \cdot{ }_{1} S^{(j)}{ }_{F}(f) d f\right]^{0.5}
$$

ここで, ${ }_{1} H^{(j)}(f): 1$ 次の周波数応答関数を表し, 次式で表される。

$$
{ }_{1} H^{(j)}(f)=\frac{1}{1-\left(\frac{f}{{ }_{1} f^{(j)}{ }_{e q}}\right)^{2}+2 i_{1} \xi^{(j)}{ }_{e q} \frac{f}{\left.{ }_{1} f^{(j)}\right)_{e q}}} \cdot \frac{1}{{ }_{1} K^{(j)}{ }_{e q}}
$$

ここに, $f$ : 振動数, ${ }_{1} f^{(j)}{ }_{e q}$ : システム 1 次等価固有振動数, $i$ : 虚数単 位を表す。なお, ${ }_{1} \xi^{(0)}{ }_{e q}$ は次式より算出される。

$$
{ }_{1} \xi^{(0)}{ }_{e q}={ }_{1} \xi=\left({ }_{1} f_{f} /{ }_{1} f\right) \cdot{ }_{1} \xi_{f}
$$

ここで, ${ }_{1} f,{ }_{1} \xi$ : システムの弾性 1 次固有振動数, 減衰定数, ${ }_{1} f_{f},{ }_{1} \xi_{f}$ : フレームの 1 次固有振動数，減衰定数を表す。風応答時における多 質点系での層間変形の標準偏差 ${ }_{1} \sigma^{(j)}{ }_{\delta_{i}}$ は, 式(11)で表される。

$$
\left.{ }_{1} \sigma^{(j)}\right)_{\delta i}{ }_{1} \sigma^{(j)}{ }_{q} \cdot\left({ }_{1} \phi^{(j)}{ }_{e q, i}-{ }_{1} \phi^{(j)}{ }_{e q, i-1}\right)
$$

$i$ 層の層間変形 $\delta^{(j)}{ }_{i}$ は, 式(12)より算出される。

$$
\delta^{(j)}{ }_{i=1} \sigma^{(j)}{ }_{\delta i} \cdot g^{(j)}{ }_{p}
$$

ここで, $g^{(j)}{ }_{p}:$ ピークファクターを表し ${ }^{13)}$, 次式より算出される（附 録 C)。

$$
g_{p}^{(j)}=\sqrt{2 \ln \left(600_{1} f^{(j)}{ }_{e q}\right)+1.2}
$$

層せん断力 $Q^{(j)}{ }_{i}$ は, $\delta^{(j)}{ }_{i}$ および $k^{(j)}{ }_{e q, i}$ を用いて次式で算出される。

$$
Q^{(j)_{i}}=k^{(j)}{ }_{e q, i} \cdot \delta^{(j)_{i}}
$$

[手順 3] $\boldsymbol{k}^{(j+1)}{ }_{e q, i}$ の算出

$i$ 層のシステム等価剛性 $k^{(j+1)}{ }_{e q, i}$ は, 次式より算出される。

$$
k^{(j+1)}{ }_{e q, i}=\left\{\begin{array}{cc}
k_{i} & \left(\delta^{*(j+1)}{ }_{i, \max }<\delta_{a y i}\right) \\
\left\{Q_{y i}+k_{f i}\left(\delta_{i}^{*(j+1)}-\delta_{a y i}\right)\right\} / \delta^{*(j+1)}{ }_{i} & \left(\delta^{*(j+1)}{ }_{i, \max } \geq \delta_{a y i}\right)
\end{array}\right.
$$

ここで, $\delta^{*(j+1)}{ }_{i}$ : システムの復元力特性上の $Q^{(j)}{ }_{i}$ における最大変形 を表し, 次式より算出される。

$$
\delta^{*(j+1)}{ }_{i}=\left\{\begin{array}{cc}
\left.Q^{(j)}\right)_{i} / k_{i} & \left(Q^{(j)}{ }_{i}<Q_{y i}\right) \\
\left(Q^{(j)}{ }_{i}-Q_{y i}+k_{f i} \cdot \delta_{a y i}\right) / k_{f i} & \left(Q^{(j)}{ }_{i} \geq Q_{y i}\right)
\end{array}\right.
$$

[手順 4] $\quad \boldsymbol{\xi}^{\left({ }^{(j+1)}{ }_{e q}\right.}$ の算出

システムの 1 次等価減衰定数 $\xi^{(j+1)}{ }_{e q}$ は次式で算出される。

$$
{ }_{1} \xi^{(j+1)} e_{e q}=\frac{\sum_{i=1}^{N} \xi^{(j+1)} e_{e q, i} \cdot W^{(j+1)}{ }_{i}}{\sum_{i=1}^{N} W^{(j+1)}{ }_{i}}+{ }_{1} \xi
$$

ここで, ${ }_{1} \xi^{(j+1)}{ }_{e q, i}: i$ 層の減衰定数を表し, 風応答は多様な振幅を持つ ランダム応答であることを考慮し ${ }^{14)}{ }^{16)},{ }_{1} \xi^{(j+1)}{ }_{e q, i}$ は以下の式より算 出される ${ }^{17)}$ 。

$$
\begin{aligned}
& { }_{1} \xi^{(j+1)_{e q, i}}=\left\{\begin{array}{cr}
0 & \left(\delta^{*(j+1)}{ }_{i}<\delta_{a y i}\right) \\
\frac{2\left(1+\alpha_{i}\right)}{\pi \mu^{(j+1)_{i}}} \ln \frac{\left.\mu^{(j+1)}\right)_{i}+\alpha_{i}}{\left(1+\alpha_{i}\right)\left(\mu^{(j+1)_{i}}\right)_{i}^{\left(1+\alpha_{i}\right)}} & \left(\delta^{*(j+1)}{ }_{i} \geq \delta_{a y i}\right)
\end{array}\right. \\
& \alpha_{i}=\frac{k_{a i}}{k_{f i}}
\end{aligned}
$$

ここに, $\mu^{(j+1)}: i$ 層の塑性率を表し, 次式より算出される。

$$
\mu^{(j+1)}{ }_{i}=\delta^{*(j+1)} i / \delta_{a y i}
$$

また，式(17)中の $W^{(j+1)}{ }_{i}$ は $i$ 層のポテンシャルエネルギーを表し次式 より算出される。

$$
W_{i}^{(j+1)}=\left(Q^{(j)_{i}}\right)^{2} /\left(2 \cdot k^{(j+1)}{ }_{e q, i}\right)
$$

\section{[手順 5] $1 \xi^{(j+1)}{ }_{e q}$ の判定}

${ }_{1} \xi^{(j+1)}{ }_{e q}$ と ${ }_{1} \xi^{(j)}{ }_{e q}$ が概放一致すれば（本報では $1 \%$ 以内）， システム 弾塑性時の減衰を評価したことになるので終了となる。なお, 層間変 形は, 手順 2 の式(12)より算出した值を用いる。もし一致しなければ, $j=j+1$ とし手順 1 一戻る。

\section{4. 提案手法の予測精度}

Fig. 10 に弾塑性解析結果（Time history analysis (Plastic)）および提 案手法 (Proposed method) の層間変形角 $R_{i}$ を比較した図を示す。な お, 参考として弾性解析結果 (Time history analysis (Elastic)) の $R_{i}$ も 併記する。また Fig. 10 中には, フレームの 1 次減衰定数 $\xi_{f}$, システ 么弾性時の 1 次減衰定数 ${ }_{1} \xi, 1$ 次固有周期 ${ }_{1} T$, 提案手法により算出 した 1 次等価減衰定数 ${ }_{1} \xi_{e q}, 1$ 次等価固有周期 ${ }_{1} T_{e q}$ および収斂回数 $j$ も併せて示す。本章では予測精度の検証のため, 2.1 節で述べた解析 対象モデル（Case 1)，一部の付加系の降伏層せん断力を低減した場 
合 (Case 2), 11 層目から 20 層目までの付加系を弾性とした場合 (Case 3）の 3 パターンで検討を行う。 ${ }_{1} \xi_{e q}$ と $j$ の関係および ${ }_{1} T_{e q}$ と $j$ の関係 については附録 D を参照されたい。

\section{[Case 1] 解析対象モデル}

Fig. 10 Case 1 より, 弾塑性解析結果と弾性解析結果を比較してい くと, ${ }_{1} \xi_{f}=1 \%, 2 \%$ では弾塑性解析結果の值が小さいことがわかる。 これは付加系の塑性化により, 減衰が増加したことが影響している。 一方で ${ }_{1} \xi_{f}=4 \%$ の場合は，概初同值となっている。これは塑性化する 付加系が少なくシステム全体として概ね弾性状態であるからである。 弾塑性解析結果と提案手法を比較していくと, 全てのパターンに おいて精度よく一致していることが確認できる（附録 E)。また ${ }_{1} \xi_{f}=$ $1 \%, 2 \%$ において提案手法により算出した ${ }_{1} \xi_{e q},{ }_{1} T_{e q}$ は, ${ }_{1} \xi,{ }_{1} T$ よりも 比較的大きくなっていることがわかる。しかし， ${ }_{1} \xi_{f}=4 \%$ の場合は, 前述したようにシステム全体が概补弾性状態であることから弾性解 析結果と提案手法がほぼ変化していない。また提案手法により算出 した ${ }_{1} \xi_{e q},{ }_{1} T_{e q}$ は， ${ }_{1} \xi,{ }_{1} T$ と概㸚同等である。このようなシステム全 体として概ね弾性状態である場合は, システム弾性時の值でも予測 可能である。

\section{[Case 2] 一部の付加系の降伏層せん断力を低減した場合}

局所的に変形が増大寸る場合を想定し，文献 7)を参考に， $i$ 層の付 加系の降伏層せん断力を低減する。本報では，1 層目と 10 層目の付
加系の降伏層せん断力を 0.5 倍とし検討を行う。なお, システムの弾 性 1 次固有周期が Case 1 と同值になるように付加系の剛性は変化さ せない。また, 弱層とした層の付加系の降伏変形は, 式(4), (5)を用 いて逆算的に計算することにより算出する。

Fig. 10 Case 2 より, 弾塑性解析結果と弾性解析結果を比較してい くと, 弾塑性解析結果が Case 1 より小さくなっており, わずかに弾 性解析結果との差が広がっていることがわかる。次に弾塑性解析結 果と提案手法を比較していくと, Case 1 と同様に, 全てのパターンに おいて弾塑性解析結果と提案手法が精度よく一致していることが確 認でき（附録 $\mathrm{E})$ ，弱層における局所的な変形も本手法は的確に捉え ていることがわかる。また, 提案手法により算出した ${ }_{1} \xi_{e q},{ }_{1} T_{e q}$ が Case 1 に比べわずかに大きくなっていることが確認できる。これは, 弱層 で大きく塑性化したことが影響しているためである。

\section{[Case 3] 11 層目から 20 層目までの付加系を弾性とした場合}

実際の超高層建物の設計において, ダンパーを下層部のみ配置し, 上層部に弾性ブレースを配置する場合がある。そこで Case 3 では, そのような配置形式を想定し，1 層目から 10 層目の付加系のみ塑性 化を許容し，11 層目から 20 層目の付加系を弾性とした場合で検討を 行う。

Fig. 10 Case 3 より, 弾塑性解析結果と弾性解析結果を比較してい くと，全てのパターンにおいて Case 1 と概ね同様の結果となってい

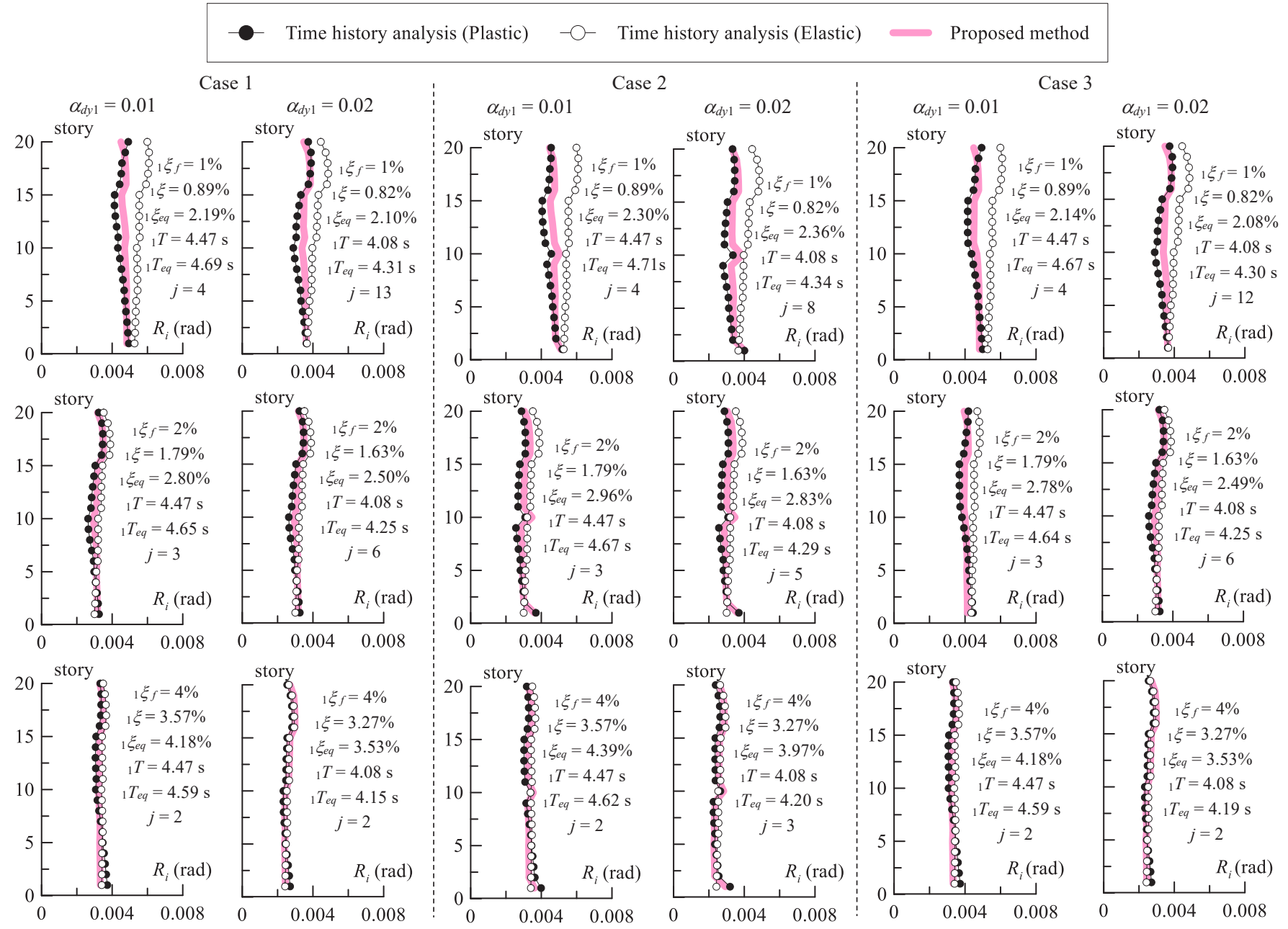


ることが確認できる。弾塑性解析結果と提案手法を比較していくと, Case 1 と同様に, 全てのパターンにおいて弾塑性解析結果と提案手 法が精度よく一致していることが確認でき（附録 $\mathrm{E})$, 提案手法によ り算出した ${ }_{1} \xi_{e q},{ }_{1} T_{e q}$ においても, Case 1 と同様の傾向が見られる。

\section{5. おわりに}

本報では, 履歴型ダンパーを有する超高層制振建物を対象とし, 多 質点系での風応答（最大変形）予測手法を提案し，その精度について 示すことを目的に検討を行った。以下に得られた知見を示す。

(1). 解析対象モデル (Case 1) のシステム弾塑性時の時刻歴解析結 果（弾塑性解析結果）およびシステム弾性時の時刻歴解析結果 (弾性解析結果) の層間変形角 $R_{i}$ を比較した結果, フレームの 1 次減衰定数 ${ }_{1} \xi_{f}=1 \%$ よび $2 \%$ においてはダンパー量 $\alpha_{d y 1}$ に関 わらず，弾塑性解析結果の值が小さいことがわかった。これは 付加系の塑性化により, 減衰が増加したことが影響している。 一方で ${ }_{1} \xi_{f}=4 \%$ の場合は，概祆同值となることがわかった。こ れは塑性化する付加系が少なくシステム全体として概补弾性 状態であるからである。

(2). Case 1 の弾塑性解析結果と提案手法の $R_{i}$ を比較した結果, 全て のパターンで精度よく一致することが確認された。また，提案 手法により算出したシステム 1 次等価減衰定数 ${ }_{1} \xi_{e q}, 1$ 次等価 固有周期 ${ }_{1} T_{e q}$ は, システム弾性時の 1 次減衰定数 ${ }_{1} \xi, 1$ 次固有 周期 ${ }_{1} T$ よりも比較的大きいことがわかった。しかし，概㸚弾性 状態である ${ }_{1} \xi_{f}=4 \%$ の場合は, システム弾性時と弾塑性時の值 が概ね一致していることからシステム弾性時の值でも予測可 能である。

(3). 解析対象モデルの 1 層目と 10 層目の付加系の降伏せん断力を 0.5 倍とした場合 (Case 2) において, 弱層を設けない場合 (Case 1) と同様に, 全体として精度よく提案手法と弾塑性解析結果が 一致し, 弱層における局所的な変形も本手法は的確に捉えるこ とが可能である。また， $\xi_{e q},{ }_{1} T_{e q}$ が弱層を設けない場合に比心゙ わずかに大きくなっていることが確認された。これは, 弱層で 大きく塑性化したことが影響している。

(4). 解析対象モデルの 11 層目から 20 層目の付加系を弾性とした場 合（Case 3）において, 弾塑性解析結果と提案手法を比較した 結果, Case 1 と同様に, 全てのパターンにおいて弾塑性解析結 果と提案手法が精度よく一致していることが確認された。 なお, 本報では限られた範囲での予測精度について検討した。本手 法の適用範囲については, さらなる検討が必要である。

\section{謝辞}

本研究の一部は, JST 産学競争プラットフォーム共同研究推進プロ グラムによるものです。ここに記して感謝の意を示します。

\section{参考文献}

1）大熊武司, 神田順, 田村幸雄 : 建築物の耐風設計, 鹿島出版会, 2004.6

2）吉江慶祐, 北村春幸, 大熊武司, 和田章 : 時刻歴応答解析におけるアンサ ンブル平均のばらつき, 日本建築学会学術講演梗概集, pp. $233-234$, 2005.7

3) Tsujita O., Hayabe Y., Ohkuma T., Wada A. : A Study on Wind Induced Characteristic and Prediction for Inelastic Structure Part. 1 A Case of
Across Wind Vibration, Journal of Structural and Construction Engineering (Transactions of AIJ), No. 481, pp. 9 - 16, 1996.3 (In Japanese)

辻田修, 早部安弘, 大熊武司, 和田章: 弾塑性構造物の風応答性状ならび にその予測に関する研究 その 1 風直角振動の場合, 日本建築学会構造 系論文集，第 481 号，pp. 9 - 16, 1996.3

4) Yoshie, K., Kitamura, H., Okuma, T. Wada A. : A Prediction Method for Response of an Elasto-Plastic Structure to Wide-Band Fluctuating Wind Force with Non-Zero Mean Component based on Energy Balance, Journal of Structural and Construction Engineering (Transactions of AIJ), No. 608, pp.21 - 28, 2006.10 (In Japanese)

吉江慶祐, 北村春幸, 大熊武司, 和田章 : エネルギーの釣合に基づく平均 成分を有する広帯域性変動風力を受ける弹塑性構造物の応答予測手法, 日 本建築学会構造系論文集，第 608 号，pp.21-28，2006.10

5) Tsujita O., Hayabe Y., Ohkuma T., Wada A. : A Study on Wind Induced Characteristic and Prediction for Inelastic Structure Part. 4 Application to multi-mass system, Journal of Structural and Construction Engineering (Transactions of AIJ), No. 499, pp. $39-45,1997.9$ (In Japanese)

辻田修, 早部安弘, 大熊武司, 和田章: 弾塑性構造物の風応答性状ならび にその予測に関する研究 その 4 多質点モデルへの展開, 日本建築学会 構造系論文集，第 499 号，pp. 39 - 45, 1997.9

6）鶴見俊雄, 片桐純治, 大熊武司, 大内隼人, 工藤愛架 : 高層免震建築物の 等価線形モデルによる風応答解析 その $1 \sim 4$, 日本建築学会学術講演梗概 集, pp. $163-170,2015.9$

7) Sato, D., Ikegami, M., Hirai, H., Yoshie, K., Sato, T., Kitamura, H., : Cumulative Damage Prediction for Passive Controlled High-Rise Building with Hysteretic Dampers on Wind-Induced Response, Journal of Structural and Construction Engineering (Transactions of AIJ), Vo1.81, No.728, pp.1635-1645, 2016.10 (In Japanese) 佐藤大樹, 池上昌志, 平井宏幸, 吉江慶祐, 佐藤利昭, 北村春幸 : 履歷型 ダンパーを有する超高層制振建物の風応答時における累積損傷分布予測, 日本建築学会構造系論文集, 第 81 巻, 第 728 号, pp.1635-1645, 2016.10

8) Sato D., Kasai K., Tamura T. : Influence of Frequency Sensitivity of Viscoelastic Damper on Wind - Induced Response, Journal of Structural and Construction Engineering (Transactions of AIJ), Vol. 74, No. 635, pp. $75-82,2009.1$ (In Japanese)

佐藤大樹, 笠井和彦, 田村哲郎 : 粘弾性ダンパーの振動数依存性が風応答 に与える影響, 日本建築学会構造系論文集, 第 74 巻, 第 635 号, pp. 75 $82, \quad 2009.1$

9) Kuribayashi, K., Sato, D., Kitamura, H., Yamaguchi, M., Nishimoto, K., : Energy Balance-Based Seismic Response Prediction Method for Steel Structure considering Effective Hysteretic Damper Deformation, Journal of Structural and Construction Engineering (Transactions of AIJ), Vol. 76, No. 661, pp. 543 - 552, 2011.3 (In Japanese)

栗林晃司, 佐藤大樹, 北村春幸, 山口路夫, 西本晃治: 実効変形を考慮し た履歷減衰型制振部材を有する鋼構造建物のエネルギーの釣合に基づく応 答予測法, 日本建築学会構造系論文集, 第 76 巻, 第 661 号, pp. $543-552$, 2011.3

10) Ishii M., Kasai K. : Shear Spring Model for Time History Analysis of Multi - Story Passive Controlled Buildings, Journal of Structural and Construction Engineering (Transactions of AIJ), Vol. 75, No. 647, pp. 103 - 112, 2010.1 (In Japanese)

石井正人, 笠井和彦: 多層制振構造の時刻歴解析に用いるせん断棒モデル の提案, 日本建築学会構造系論文集, 第 75 巻, 第 647 号, pp. $103-112$, 2010.1

11) 中島隆裕, 添田幸平: 制振ダンパーのエネルギー吸収メカニズムの比較, 建築技術，pp. 130 - 133，2016.5

12) Higashino M., Ohtake K., Hamaguchi H., Wada A. : Durability of Sliding Isolation Device Employed in Super High Rise Buildings Subjected to Wind Excitations, Journal of Structural and Construction Engineering (Transactions of AIJ), Vol. 75, No. 648, pp. 317 -325, 2010.2 (In Japanese) 東野雅彦, 大竹和夫, 浜口弘樹, 和田章 : 風外力を受ける超高層免震構造 
における滑り支承の耐久性に関する研究, 日本建築学会構造系論文集, 第 75 巻, 第 648 号, pp. $317-325,2010.2$

13) 日本建築学会 : 建築物荷重指針・同解説 (2015), 2015

14) N. M. Newmark and E. Rosenblueth : Fundamentals of Earthquake Engineering, Prentice - Hall Inc, 1971

15) W. D. Iwan and N. C. Gates : Estimating Earthquake Response of simple Hysteretic Structure, Journal of Engineering Mechanics Division, ASCE, pp. $391-405,1979$

16) K. kasai, Y. Fu, A. Watanabe : Passive Control Systems for Seismic Damage Mitigation, Journal of Structural Engineering, ASCE, Vol. 124, No. 5, pp. $501-512,1998$

17) Takeuchi T., Ichikawa Y., Nakashima H., Kasai K. : Response Evaluation of Passively Controlled Multistory Building with Non-Uniform Damper Distribution, Journal of Structural and Construction Engineering (Transactions of AIJ), No. 583, pp. 115 -122, 2004.9 (In Japanese)

竹内徹, 市川康, 中島秀雄, 笠井和彦: ダンパーが不均一配置された多層 パッシブ制振構造の応答予測, 日本建築学会構造系論文集, 第 583 号, pp. $115-122,2004.9$

\section{附録 $\mathrm{A}$ 風洞実験}

Fig. A1 に風洞気流特性の鉛直分布を, Fig. A2 に模型頂部高さ $(300 \mathrm{~mm})$ で の変動風速の無次元化パワースペクトル密度（PSD）を示寸。Fig. A1 中に示す $H^{*}$ は，風洞床面からの高さを表し， $U(\mathrm{AIJ}), I_{u}(\mathrm{AIJ})$ は文献 13)上り算出する平 均風速および乱独さの鉛直分布, $U\left(\right.$ Exp.),$I_{u}$ (Exp.) は風洞実験における平均 風速および乱れ強さの鉛直分布を表す。また, Fig. A2 中の $S_{u}(f), \sigma_{u}$ は, 風速 のパワースペクトル密度, 標準偏差, $L_{x}$ は乱れのスケールを表し $(=0.53 \mathrm{~m})$, Fig. A2 中にカルマン型 ${ }^{13)}$ の無次元化 PSD も併記している。なお, 基準高さ (模 型上 $300 \mathrm{~mm}$ ) での平均風速は $10.0 \mathrm{~m} / \mathrm{s}$ である。Fig. A1, A2 ともに, 実験值が 指針值（Fig.A1：AIJ，Fig.A2：Von karman）と精度よく一致していることが碓 認できる。
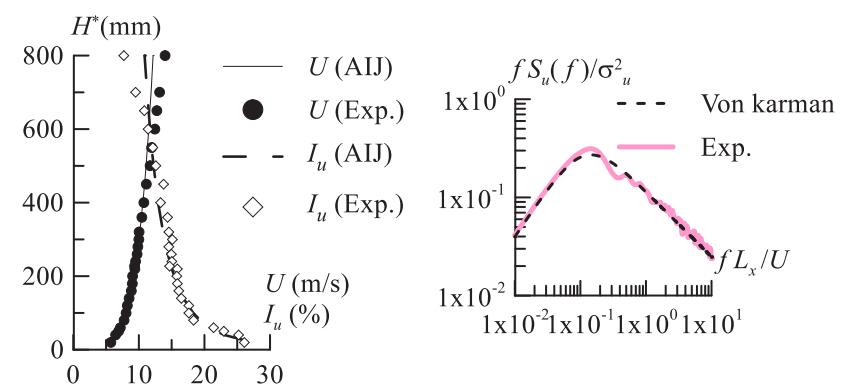

Fig. A1 Vertical distribution of wind tunnel airflow characteristics

Fig. A2 Power spectral density

\section{附録 B 1 次等価固有モード}

Fig. B に 1 次等価固有モードの差 ${ }_{1} \phi_{e q, i-1} \phi_{e q, i-1}$ と収斂回数 $j$ の関係を示す。な お，代表例としてそれぞれのケースで最もステップ数が多かった $\alpha_{d y 1}=0.02$, ${ }_{1} \xi_{f}=1 \%$ における結果を示している。Fig. B より, 全てのケースにおいて $j>0$ で ${ }_{1} \phi_{e q, i-1} \phi_{e q, i-1}$ が $j=0$ に比べ変化していることが確認できるが, $j>0$ の場合に おける $j$ の増加に伴う $1 \phi_{e q, i}-1 \phi_{e q, i-1}$ の変化はほとんど見られないことがわかる。
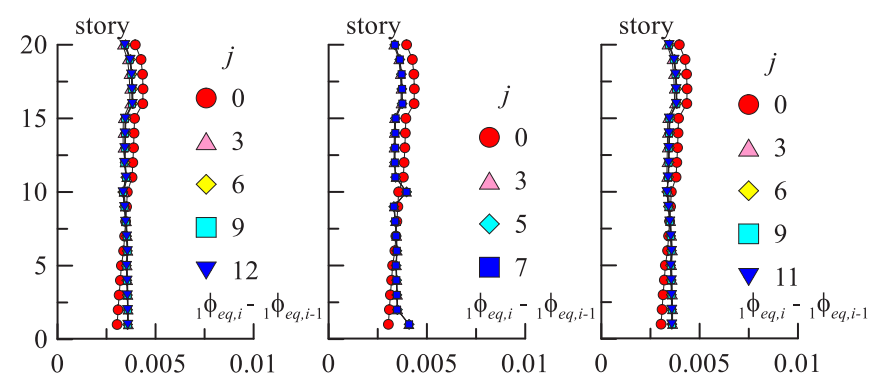

(a) Case 1
附録 C ピークファクター

Fig. C にピークファクター $g_{p}$ の弾塑性解析結果と予測值（式(13)）を比較し たもの示す。なお，代表例として Case 1，2，3の $\alpha_{d y 1}=0.01 ， 1 \xi_{f}=1 \%$ 時におけ る值を示している。Fig. Cより，Case 1，2，3 ともに，下層部において予測值 の $g_{p}$ が弾塑性解析結果よりも小さく評価されているが，上層部においては概 ね一致する傾向が見られる。

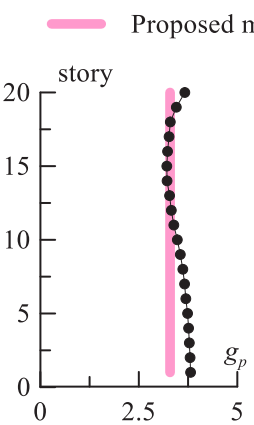

(a) Case 1

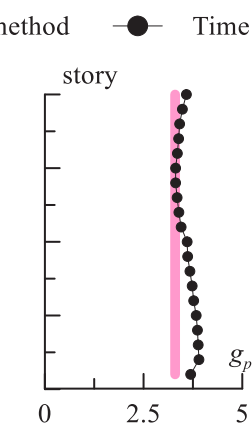

(b) Case 2
Time history analysis

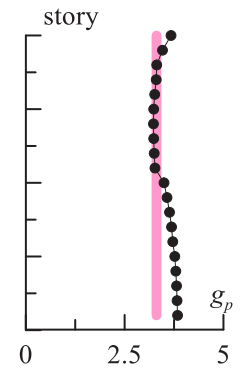

(c) Case 3
Fig. C Peak factor $\left(\alpha_{d y 1}=0.01,{ }_{1} \xi_{f}=1 \%\right)$

附録 D 1 次等価減衰定数および 1 次等価固有周期とステップ数の関係

Fig. D に Case 1 3 における 1 次等価減衰定数 ${ }_{1} \xi_{\text {eq }}$ および 1 次等価固有周期 ${ }_{1} T_{e q}$ と収斂回数 $j$ の関係を示す。なお, それぞれ $j=15$ までの結果であり, 代 表例として ${ }_{1} \xi_{f}=1 \%$ 時における関係を示している。Fig. D より, $j$ が増加する とともに ${ }_{1} \xi_{e q},{ }_{1} T_{e q}$ が一定值に収束していることが確認できる。

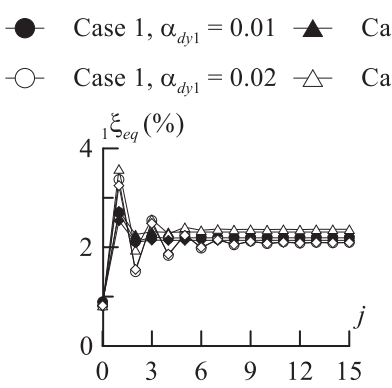

(a) $1 \xi_{e q}$

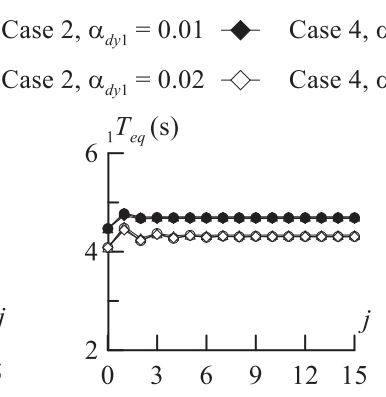

(b) $1 T_{\text {eq }}$
Fig. D Relation of ${ }_{1} \xi_{\text {eq }}, 1 T_{\text {eq }}$ and $j\left(1 \xi_{f}=1 \%\right)$

\section{附録 $\mathrm{E}$ 最大塑性率と誤差率の関係}

Fig. E(a) (c) に Case 1 3 における層間変形角の誤差率と弾塑性解析結果の 最大塑性率 $\mu_{i}$ の関係図を示す。Fig. E(a) (c)より, どのケースにおいても $\mu_{i}=1$ ２の間で誤差が大きくなる傾向が見られるが，全体として誤差は概补 $15 \%$ 以 内となっていることが確認できる。 $\xi_{1}=1 \%, \alpha_{d y 1}=0.01$

$\xi_{f}=1 \%, \alpha_{d y 1}=0.02$

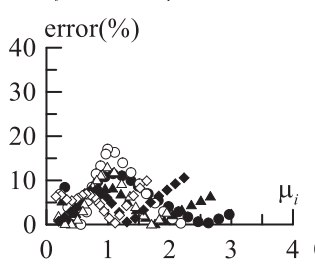

(a) Case 1
$\boldsymbol{\Delta}_{1} \xi_{f}=2 \%, \alpha_{d y 1}=0.01$ $\triangle_{1} \xi_{f}=2 \%, \alpha_{d y 1}=0.02$ error $(\%)$

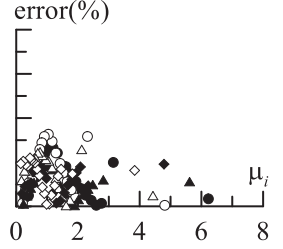

(b) Case 2
${ }_{1} \xi_{f}=4 \%, \alpha_{d y 1}=0.01$ $\diamond_{1} \xi_{f}=4 \%, \alpha_{d y 1}=0.02$ error(\%)

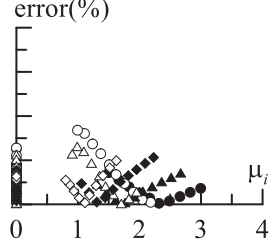

(c) Case 3
Fig. E Relation of percentage error and $\mu_{i}$ [2020 年 10 月 7 日原稿受理 2020 年 12 月 7 日採用決定］

Fig. B Relation of ${ }_{1} \Phi_{\text {eq }, i-1} \Phi_{\text {eq, },-1}$, and $j\left(\alpha_{d y 1}=0.02,1 \xi_{f}=1 \%\right)$ 